\title{
The Influence of Usage of Tourniquet in Total Knee Arthroplasty on Serum Ischemia Modified Albumin Levels
}

\section{Total Diz Artroplastisinde Turnike Kullanımının Serum İskemi Modifiye Albümin Seviyeleri Üzerine Etkisi}

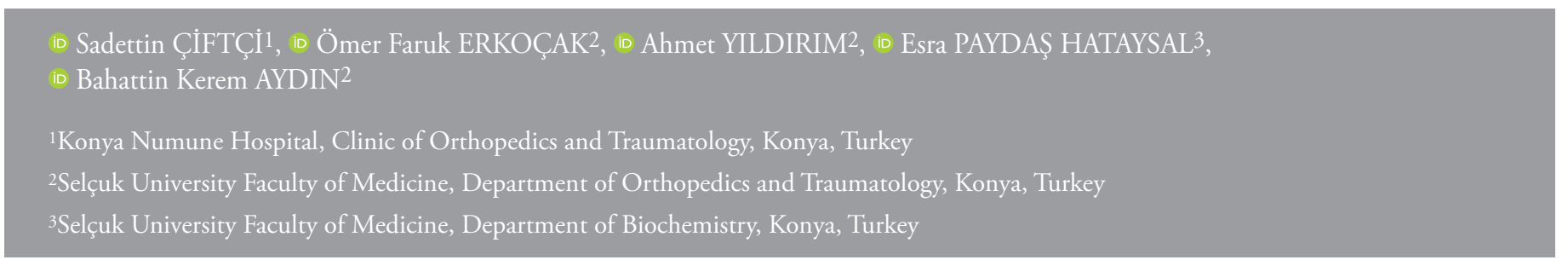

\section{ABSTRACT}

Objective: Ischaemia-modified albumin (IMA) has frequently been studied in recent years in ischaemia-based studies. In this study, IMA changes and postoperative pain were investigated in patients who underwent tourniquet and non-tourniquet knee arthroplasty, and the effect of the tourniquet on pain was investigated quantitatively.

Methods: After obtaining institutional review board approval, 64 patients who underwent total knee arthroplasty were divided into two groups: tourniquet and non-tourniquet using the block randomisation technique. Blood was collected at the 15 th minute and 24 th hour postoperatively. A visual analogue scale (VAS) was used by patients to evaluate their pain.

Results: According to the results, a significant correlation was found between VAS scores and IMA levels in the blood taken at the postoperative 15 th minute $(\mathrm{p}<0.001)$. In addition, IMA levels were significantly higher in the tourniquet group $(\mathrm{p}<0.001)$.

Conclusion: Less frequent loss of quadriceps muscle strength, less postoperative pain and avoidance of ischaemia-related complications are the main advantages of non-tourniquet knee arthroplasty. IMA is effective in demonstrating these advantages and can be used for problems such as compartment syndrome, which may be accompanied by muscle damage in the extremity.

Keywords: Ischemia modified albumin, knee arthroplasty, tourniquet

\section{ÖZ}

Amaç: İskemi modifiye albümin (IMA) son yıllarda iskemi temelli çalışmalarda sıkça incelenmiştir. Bu çalışmada turnikeli ve turnikesiz diz artroplastisi uygulanan hastalarda IMA değişimleri ve postoperative ağrı incelenmiş olup turnikenin diz artroplastisinde ağrı üzerine etkisi kantitatif olarak araştırılmıştır.

Yöntemler: Kurumsal Etik kurul onayının alınmasının ardından diz artroplastisi uygulanmış 64 hasta blok randomizasyon tekniği ile turnikeli ve turnikesiz olarak iki gruba ayrıld. Preoperatif, postoperative 15 . dakika ve 24 . saatlerde kan alındı. VAS skorlaması kullanılarak ağrı düzeyleri değerlendirildi.

Bulgular: Elde edilen verilere göre postoperatif 15.dakikada alınan kanda incelenen IMA değeri ile VAS değeri arasında anlamlı korelasyon tespit edilmiştir $(\mathrm{p}<0,001)$ Ayrıca IMA değerleri turnikeli grupta anlamlı olarak yüksek bulunmuştur $(\mathrm{p}<0,001)$.

Sonuç: Quadriceps kas gücü kaybının daha az olması, postoperatif ağrının daha az olması, iskemiye bağlı komplikasyonlardan kaçınılmış olması turnikesiz diz artroplastisi uygulamasının temel avantajlarıdır. İMA bu avantajların gösterilmesinde etkin olduğu gibi, ekstremitede kas hasarının eşlik edebildiği kompartman sendromu gibi problemlerde de kullanılabilecektir.

Anahtar Sözcülkler: İskemi modifiye albümin, diz artroplastisi, turnike
Address for Correspondence: Saadettin ÇiFTçi, Konya Numune Hospital, Clinic of Orthopedics and Traumatology, Konya, Turkey

E-mail: dr.sadettinciftci@gmail.com ORCID ID: orcid.org/0000-0003-3249-3420

Tourniquet in Total Knee Arthroplasty on Serum Ischemia Modified Albumin Levels.

Bezmialem Science 2020;8(4):383-387. 


\section{Introduction}

Knee arthroplasty is a surgical procedure with successful results in over $90 \%$ of cases when pain and functional recovery are considered based on cases of gonarthrosis during advanced age (1). The use of a tourniquet in knee arthroplasty has been examined regarding pain, function, muscle strength and prosthesis survival. It is unquestionable that a tourniquet facilitates surgical exposure; however, studies indicate that there is no benefit of tourniquet use other than showing a positive effect in cement adhesion (24). It is also thought that tourniquets increase postoperative pain due to ischaemia and nerve compression. However, studies on this subject have not shown a quantitative value that would be a significant ischaemia criterion $(2,5,6)$.

The use of a tourniquet in knee arthroplasty has been associated with increased risk of deep venous thrombosis (7), wound healing impairment (8) and postoperative pain $(8,9)$. A limited number of markers are significant in the literature to investigate the presence and possible consequences of ischaemia. Ischaemiamodified albumin (IMA) is a derivative of albumin. It is known that a reduction occurs in the metal binding capacity of albumin by the modification of the $\mathrm{N}$-terminal end of the albumin caused by hydroxyl ions formed as a result of oxidative stress $(10,11)$. IMA, which is known to be elevated in the event of ischaemia, has been accepted as a quantitative marker for ischaemia and investigated in many pathologies, including cardiac ischaemia, abdominal compartment syndrome and asthma attacks (12).

The aim of this study is to investigate the effect of ischaemia and oxidative stress on pain occurring after knee arthroplasty.

\section{Method}

Approval was obtained for this prospective, randomised controlled trial from the local Ethics Committee with decision numbers 2017/161. Sixty-four patients who underwent unicompartmental knee arthroplasty were divided into two groups, tourniquet and non-tourniquet, using the block randomisation technique; homogeneity was provided between the groups.

Patients with a history of symptomatic diabetic microangiopathy, cardiovascular disease, peripheral arterial disease and previous extremity surgery within the last three months were excluded from the study.

In all patients, $2 \mathrm{~g}$ cefazolin was administered perioperatively, and $4^{*} 1 \mathrm{~g}$ perioperatively over 24 hours as perioperative antibiotic prophylaxis. In all patients, standard posterior cruciate ligaments cutting posterior-stabilised designs were preferred. All procedures were performed by two different surgeons with at least five years' experience in knee arthroplasty. Hemovac drains were placed as a standard procedure to prevent hemarthrosis. Five hundred milligrammes of tranexamic acid was injected into the joint in all patients during the postoperative period to reduce blood loss. Blood was collected from the cubital fossa veins before tourniquet application at the $15^{\text {th }}$ minute $(\mathrm{min})$ and $24^{\text {th }}$ hour postoperatively by the same person.
A visual analogue scale (VAS) was used by patients to evaluate their pain (Figure 1).

The blood taken from patients for IMA measurement was placed into serum-separating tubes and centrifuged at $3000 \mathrm{rpm}$ for 10 min using a Sigma centrifuge. Serum samples were placed in Eppendorf tubes for 1 hour and kept at $-80{ }^{\circ} \mathrm{C}$ until the time of the study. From the dissolved patient serum, $200 \mathrm{gL}$ was placed into the sample tube and $200 \mathrm{gL}$ into the blank tube. Fifty microliters of $1 \mathrm{~g} / \mathrm{L} \mathrm{CoCI}_{2}$ (Cobalt-2-chloride)(Merck, K102539.0100, Darmstadt, Germany) was added to both the sample tube and the blank tube. The prepared mixture was mixed with a vortex and allowed to incubate for 10 minutes at room temperature. After $10 \mathrm{~min}, 50 \mathrm{gL} 1.5 \mathrm{~g} / \mathrm{L}$ DTT (dithiothreitol) (Merck, K111474.0005, Darmstadt, Germany) was added to the sample tube. This was kept at room temperature for two min to observe the colour change. After two min, $1 \mathrm{~mL}$ of normal saline $(0.9 \% \mathrm{NaCl})$ was added to both the sample and blank tubes. Absorbances were measured at $470 \mathrm{~nm}$ in a Perkin Elmer Lambda 25 Spectrophotometer. The sample and blank tube results were recorded separately. The results were recorded as Absorbance Units (ABSU). In addition, IMA values of each patient were calculated according to their operation group and albumin. Albumin determination was performed on a Beckman Coulter Au 5800 device using the bromocresol green method. The results are presented as $\mathrm{mg} / \mathrm{dL}$.

Corrected IMA (ABSU,): IMA x patient's albumin/Albumin average of the group.

\section{Statistical Analysis}

The IBM SPSS Statistics Version 21 programme was used for statistical analyses. The values to be examined were subjected to normality analysis using the Shapiro-Wilk test. Student's t-test (independent sample t-test) was used to compare values between the tourniquet and non-tourniquet groups that were evaluated as parametric (sig. $>0.05$ ) in the normality test. The MannWhitney $\mathrm{U}$ test was used for the groups that were evaluated as nonparametric (sig. <0.05). In addition, for correlations between numeric values, Pearson's test was used for the groups that were evaluated as parametric in the normality test. Spearman's test was used for the groups that were evaluated as nonparametric. For the results, assessments of $\mathrm{p}<0.05$ were considered statistically significant. In the correlation evaluations, the power of significance was determined by the value of $r$.

\section{Results}

A total of 64 patients, 58 females and six males were included in the study. The mean surgical duration was determined as

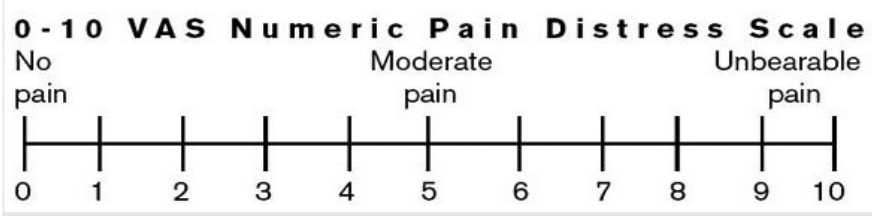

Figure 1. The visual analogue scale (VAS) 
$73.6 \pm 11.4 \mathrm{~min}$. Regarding surgical duration, the mean time of the tourniquet group was $80.4 \pm 8.7 \mathrm{~min}$, and the non-tourniquet group was $66.8 \pm 9.6 \mathrm{~min}$, and this difference was statistically significant $(\mathrm{p}<0.001)$ (Table 1$)$.

Patients had significantly higher VAS scores in the tourniquet group than the non-tourniquet group at the $12^{\text {th }}$ postoperative hour $(\mathrm{p}<0.001)$ (Table 1). A significant correlation was found between the postoperative 15th $\min$ IMA and corrected postoperative $15^{\text {th }}$ min IMA values and $12^{\text {th }}$ hour VAS scores $(\mathrm{p}<0.001)$ (Table 3). A significant positive correlation was found between VAS scores and surgical duration $(\mathrm{p}=0.002)$ (Table 3).

When IMA levels were measured preoperatively and at the $15^{\text {th }}$ min and $24^{\text {th }}$ hour postoperatively, it was determined that the postoperative $15^{\text {th }}$ min IMA and corrected IMA (13) values were significantly higher in the tourniquet group (Graph 1). However, no significant relationship was found between the two groups in the preoperative and postoperative $24^{\text {th }}$ hour IMA values. There were no significant correlations observed between patient-linked factors, such as body mass index (BMI) and age, between both groups (Table 1).

When the correlation between IMA values and surgical duration was examined, IMA values at the postoperative $15^{\text {th }} \mathrm{min}$ and corrected postoperative $15^{\text {th }} \mathrm{min}$ were found to be highly correlated with surgical duration (Table 2).

\section{Discussion}

Regarding the difference in surgical duration between the tourniquet and non-tourniquet groups, this may have been caused by the wrapping of the tourniquet to prevent infection in patients, draining the limb blood with a non-sterile esmarch bandage, the time from starting the tourniquet to inflation, and the time lost during the case preparation. No studies could be found in the literature investigating the differences in surgical duration in patients undergoing knee arthroplasty with and without tourniquets. However, Willis et al. (14) reported that long surgery time and long tourniquet time were associated with an increased infection rate. No infections were detected in our patients, and we believe that these data can be supported with more extensive case studies.
The use of a tourniquet in knee arthroplasty is an application that depends on the surgeon's preference and is reliable. Refaai et al. found that in 23 knee arthroscopy cases in which a tourniquet was used, IMA was significantly higher compared with preoperative levels in correlation with myoglobin in the material taken after the tourniquet was lowered (15). In our study, IMA and corrected IMA levels in the blood taken at the postoperative $15^{\text {th }}$ min was found to be significantly higher in the tourniquet group. In a prospective study, Wakanhar et al. (16) reported that only postoperative early flexion movements were better in knee arthroplasties performed without tourniquet application. However, there was no long-term difference, and there was no significant difference in blood volume, analgesic requirement, and postoperative pain (16). In a meta-analysis by Zhang et al. (8), non-tourniquet knee arthroplasty was found to be superior regarding thromboembolic events and associated complications. It has been reported that tourniquet use may prevent postoperative exercise, but no significant difference was found in blood loss [8]. Also, the use of tourniquets was reported to improve surgical conditions, surgical vision and reduce blood loss in different studies (5,6,17-19). Although the

Table 2. Statistical examination of correlation between surgical duration and postoparative IMA levels

\begin{tabular}{l|l|l|}
\hline & $\Gamma$ & $\mathrm{P}$ \\
\hline $\begin{array}{l}\text { Surgical duration-postoperetive } 15^{\text {th }} \text { min } \\
\text { IMA }\end{array}$ & 0.435 & $<0.001$ \\
$\begin{array}{l}\text { Surgical duration corrected postoparative } \\
15^{\text {th }} \text { min IMA }\end{array}$ & 0.298 & 0.017 \\
\hline IMA: Ischemia modified albumin & & \\
\hline
\end{tabular}

Table 3. Examination of the corelation between postoparative $15^{\text {th }}$ min IMA, VAS and surgical duration values

\begin{tabular}{|l|l|l|}
\hline Postoperetive $15^{\text {th }}$ min IMA-VAS & $\Gamma$ & $\mathrm{P}$ \\
\hline Corrected postoparative $15^{\text {th }}$ min IMA-VAS & 0.790 & $<0.782$ \\
\hline VAS-Surgical duration & 0.380 & $<0.001$ \\
\hline
\end{tabular}

IMA: Ischemia modified albumin, VAS: Visual analog scale

Table 1. Statistical evaluation of the changes in surgical duration, BMI, and age variables related to tourniquet

\begin{tabular}{|c|c|c|c|}
\hline & Tourniquet & Non-tourniquet & $p$ \\
\hline Surgical duration (minutes) & $80.4 \pm 8.7$ & $66.8 \pm 9.6$ & $<0.001$ \\
\hline Preoperative IMA & $1.06 \pm 0.03$ & $1.06 \pm 0.04$ & 0.995 \\
\hline Postoperative $15^{\text {th }} \min$ IMA & $1.25 \pm 0.21$ & $1.02 \pm 0.23$ & $<0.001$ \\
\hline Postoperative $24^{\text {th }}$ hour IMA & $1.08 \pm 0.28$ & $1.03 \pm 0.23$ & 0.528 \\
\hline VAS $12^{\text {th }}$ hour & $8.85 \pm 0.65$ & $7.95 \pm 0.73$ & $<0.001$ \\
\hline IMA first change & $-0.19 \pm 0.20$ & $0.03 \pm 0.20$ & $<0.001$ \\
\hline Corrected IMA first change & $0.20 \pm 0.27$ & $-0.0065 \pm 0.25$ & 0.002 \\
\hline BMI & $32.7 \pm 6.9$ & $32.7 \pm 3.7$ & 0.975 \\
\hline Age & $64.7 \pm 7.8$ & $63.6 \pm 6.6$ & 0.560 \\
\hline
\end{tabular}


use of a tourniquet provides better adhesion of cement, studies also reported that there is no difference (2-4). Estebe et al. (5) stated that the most important complication of a tourniquet is pain caused by mechanical compression or ischaemia-reperfusion injury. However, Spruce reported that tourniquets could be used safely when in compliance with the appropriate conditions of use. In addition, complications would be minimised to ensure the best possible visualisation of the surgical environment, reduction of blood loss, and optimisation of surgical conditions (6). Kumar et al. (19) examined pain in patients undergoing total knee arthroplasty with and without a tourniquet, and the group without a tourniquet reported less early postoperative pain and early functional return. In our study, the early VAS score and IMA values were significantly higher in the tourniquet group, which implies less postoperative early pain in the non-tourniquet group.

In the present study, a significant positive correlation was found between the postoperative $15^{\text {th }}$ min IMA and the corrected postoperative 15th min IMA values and surgical duration. It is reported in the literature that surgical duration is important, especially for pain. The duration of ischaemia and IMA correlations have been examined in abdominal compartment syndrome in the literature, and IMA levels were found to be elevated with increased ischaemic time (12). However, there are no data in the literature on limb ischaemia time and IMA levels.

IMA was found to be higher in obese cases linked to the disruption of adipose tissue oxygenation (20). In our cases, IMA levels taken 24 hours after the end of ischaemia were not significantly different between the two groups. Since there were no significant differences between the two groups regarding BMI and age values, patient characteristics, such as BMI and age, did not have a significant negative effect.

\section{Study Limitations}

The limitations of our study include the functional results, the short postoperative follow-up period regarding the evaluation of the relationship between stability and IMA, the patients' BMIs being above normal values, and working with two different surgeons. We believe that more extensive case studies can be conducted by increasing the number of patients, and perhaps more accurate results can be obtained. We believe that tourniquet application is an appropriate, accessible, and effective method for the future to examine the early effects of compartment syndrome. The less frequent loss of quadriceps muscle strength, less postoperative pain and avoidance of ischaemia-related complications are the main advantages of non-tourniquet knee arthroplasty. IMA is effective in demonstrating these advantages and can be used for problems such as compartment syndrome, which may be accompanied by muscle damage in the extremity.

\section{Conclusion}

This prospective, randomised, controlled study evaluated the effects of the use of a tourniquet in knee arthroplasty concerning IMA, which is a quantitative value. This study is unique because it is a controlled study of IMA in orthopaedic surgery.
When we evaluate our findings, it is important to remember that the use of a tourniquet in knee arthroplasty procedures is a safe method if the rules are followed. However, postoperative pain on the first day is more common in patients with tourniquets compared with those without tourniquets. In addition, we think that the tourniquet forms a controlled compartment syndrome model. Therefore, IMA is an easy marker to reach and examine during the early stages in patients with suspected compartment syndrome. However, new studies are needed to increase the value of IMA in the diagnosis of compartment syndrome and to increase its use in orthopaedic surgery.

\section{Ethics}

Ethics Committee Approval: Approval was obtained for this prospective, randomised controlled trial from the local Ethics Committee with decision numbers 2017/161.

Peer-review: Internally and externally peer reviewed.

\section{Authorship Contributions}

Surgical and Medical Practices: Ö.F.E., A.Y., Concept: S.Ç., Design: A.Y., B.K.A., Data Collection or Processing: S.Ç., E.P.H., Analysis or Interpretation: S.Ç., B.K.A., Literature Search: S.Ç.

Conflict of Interest: No conflict of interest was declared by the authors.

Financial Disclosure: The authors declared that this study received no financial support.

\section{References}

1. Sharkey PF, Hozack WJ, Rothman RH, Shastri S, Jacoby SM. Why are total knee arthroplasties failing today? Clin Orthop Relat Res 2002; 404:7-13.

2. Alcelik I, Pollock RD, Sukeik M, Bettany-Saltikov J, Armstrong PM, Fismer P. A comparison of outcomes with and without a tourniquet in total knee arthroplasty: a systematic review and meta-analysis of randomized controlled trials. J Arthroplasty 2012;27:331-40.

3. Molt M, Harsten A, Toksvig-Larsen S. The effect of tourniquet use on fixation quality in cemented total knee arthroplasty a prospective randomized clinical controlled RSA trial. Knee 2014;21:396-401.

4. Ledin H, Aspenberg P, Good L. Tourniquet use in total knee replacement does not improve fixation, but appears to reduce final range of motion: A randomized RSA study involving 50 patients. Acta Orthop 2012;83:499-503.

5. Estebe JP, Malledant Y. Pneumatic tourniquets in orthopedics. Ann Fr Anesth Reanim 1996;15:162-78.

6. Spruce L. Back to Basics: Pneumatic Tourniquet Use. AORN J 2017;106:219-26.

7. Mori N, Kimura S, Onodera T, Iwasaki N, Nakagawa I, Masuda T. Use of a pneumatic tourniquet in total knee arthroplasty increases the risk of distal deep vein thrombosis: a prospective, randomized study. Knee 2016;23:887-9.

8. Zhang W, Li N, Chen S, Tan Y, Al-Aidaros M, Chen L. The effects of a tourniquet used in total knee arthroplasty: a meta-analysis. J Orthop Surg Res 2014;9:13. 
9. Tai TW, Chang CW, Lai K, Lin CJ, Yang CY. Effects of tourniquet use on blood loss and soft-tissue damage in total knee arthroplasty: a randomized controlled trial. J Bone Joint Surg Am 2012;94:2209-15.

10. Chawla R, Goyal N, Calton R, Goyal S. Ischemia modified albumin: a novel marker for acute coronary syndrome. Indian J Clin Biochem 2006;21:77-82.

11. Zurawska-Plaksej E, Grzebyk E, Marciniak D, SzymańskaChabowska A, Piwowar A. Oxidatively modified forms of albumin in patients with risk factors of metabolic syndrome. J Endocrinol Invest 2014;37:819-27.

12. Unlüer EE, Kiliç TY, Akgöl E, Işgüven D, Vardar E, Bayol U, et al. The role of cobalt-albumin binding analysis in the diagnosis of experimental abdominal compartment syndrome in rabbits. Ulus Travma Acil Cerrahi Derg 2010;16:491-6.

13. Lippi G, Montagnana M, Salvagno GL, Guidi GC. Standardization of ischemia-modified albumin testing: adjustment for serum albumin. Clin Chem Lab Med 2007;45:261-2.

14. Willis-Owen CA, Konyves A, Martin DK. Factors affecting the incidence of infection in hip and knee replacement: an analysis of 5277 cases. J Bone Joint Surg Br 2010;92:1128-33.

15. Refaai MA, Wright RW, Parvin CA, Gronowski AM, Scott MG, Eby CS. Ischemia-modified albumin increases after skeletal muscle ischemia during arthroscopic knee surgery. Clin Chim Acta 2006;366:264-8.
16. Wakankar HM, Nicholl JE, Koka R, D’Arcy JC. The tourniquet in total knee arthroplasty. A prospective, randomised study. J Bone Joint Surg Br 1999;81:30-3.

17. Huang ZY, Pei FX, Ma J, Yang J, Zhou ZK, Kang PD, et al. Comparison of three different tourniquet application strategies for minimally invasive total knee arthroplasty: a prospective nonrandomized clinical trial. Arch Orthop Trauma Surg 2014;134:56170.

18. Kvederas G, Porvaneckas N, Andrijauskas A, Svensen CH, Ivaskevicius $\mathrm{J}$, Mazunaitis J, et al. A randomized double-blind clinical trial of tourniquet application strategies for total knee arthroplasty. Knee Surg Sports Traumatol Arthrosc 2013;21:2790-9.

19. Kumar N, Yadav C, Singh S, Kumar A, Vaithlingam A, Yadav $S$. Evaluation of pain in bilateral total knee replacement with and without tourniquet; a prospective randomized control trial. J Clin Orthop Trauma 2015;6:85-8.

20. Mehmetoğlu I, Kurban S, Yerlikaya FH, Polat H. Obesity is an independent determinant of ischemia-modified albumin. Obes Facts 2012;5:700-9. 